\title{
DCAF12L2 wt Allele
}

National Cancer Institute

\section{Source}

National Cancer Institute. DCAF12L2 wt Allele. NCI Thesaurus. Code C143037.

Human DCAF12L2 wild-type allele is located in the vicinity of Xq25 and is approximately 3 $\mathrm{kb}$ in length. This allele, which encodes DDB1- and CUL4-associated factor 12-like protein

2 , is involved in protein-protein interactions. Mutations in the gene may be associated with colorectal cancer. 